\title{
CSR should contribute to the national agenda in emerging economies - the 'Chatterjee Model'
}

\author{
Bhaskar Chatterjee ${ }^{1}$ and Nayan Mitra ${ }^{2^{*}}$
}

\begin{abstract}
Emerging economies face a plethora of social, economic and environmental issues. On the one hand, these have adverse effects that negatively impact the overall development of such economies; and on the other, they offer challenges which when addressed, help these economies to chart a course of integrated and inclusive growth, thus providing them with an opportunity for national development.

India is no different. It has rural Bharat on one side that is steeped in illiteracy, poverty on the one hand and, a literate, rich, glitzy, corporate, urban India on the other; thereby fortifying the predicaments of an emerging nation. This paper, through an analysis of the socio-economic dilemmas and challenges of an emerging nation like that of India and scrutinizing the roles and responsibilities of Corporations to combat such a quandary through CSR, introduces the 'Chatterjee Model,' that urges, from a policy-maker's point of view, that CSR should contribute to the national agenda of a country, helping it to accelerate its transition from an emerging to a developed nation.
\end{abstract}

Keywords: Chatterjee Model, Corporate Social Responsibility (CSR), National agenda, Emerging economies, India, Cycle of Conversion, Companies Act 2013, Schedule VII, CSR Implementation, Tata Housing Development Company Limited

\section{Introduction}

India, designated as one of the world's ten emerging markets in 1995 by the Clinton administration (USA), has over the years, come to be seen as everyman of emerging nations, an archetype that captures the best and worst tricks of all the most dynamic young economies (Sharma, 1999). India is a subcontinent and its diversity makes it possible to assemble almost any picture of the pitfalls and promise of emerging markets, from the rustic, rural Bharat to the smart cities in urban India. The large states like that of Uttar Pradesh, with a population of 200 million, would on its own, represent the world's sixth most populous country; and West Bengal, having a population of 90 million, (Sharma, 2012), make administrative issues complex and multifaceted. Moreover, India has an estimated 269.3 million poor residents (2013), out of which 216.5 million reside in rural India (Rao, 2013), yet, contradicting this, is the fact that Indian stocks move and down more closely in sync with the global emerging-market average than the stocks of

\footnotetext{
* Correspondence: mitra.nayan@gmail.com

2Developmental Consultant, Kolkata, India

Full list of author information is available at the end of the article
}

most other countries do, because its market is deep and diverse (Sharma, 2012). Hence, there are diversity, complexity and even contradictions in India, as an emerging nation.

Thus, the problem statement of this research paper is 'To introduce a CSR model that will specifically combat the challenges and dilemmas of an emerging economy (here, India); contribute to its National agenda and thereby help to take it to the next level.' Therefore, the research objectives and questions that needs to be pursued are as follows:

a) What are the socio-economic dilemmas and challenges of an emerging nation?

b) What are the various national agendas in such economies?

c) What are the different roles and responsibilities of Corporations through its CSR to combat such a quandary?

d) What is the 'Chatterjee Model?' What are its main propositions?

e) Can a mini Case Study be used to illustrate the model? 
Thus, this paper not only introduces a new CSR model named the 'Chatterjee Model' that we will find, is distinctly different from the other CSR models like the Porter's 'shared value', Elkington's 'triple bottom line' and Prahalad's 'Fortune at the bottom of the pyramid'; but is also unique as it has already established itself as a legislation in the world's largest democracy, India. Thus, this paper is a great contribution to the body of knowledge of mandated CSR in emerging economies (here, India). In this context, one must remember, that researches on mandated CSR are a new field of study as CSR statute in India, itself, has been introduced only in the year 2013 and has come into effect from Financial Year 2014-15. By using the term 'mandated CSR' in the context of India, we refer to the Section 135 of the Companies Act 2013 that was introduced in India after replacing the 57 years old Companies Act 1956. This Section, among many other things mandates every company covered by the inclusion criteria to spend at least $2 \%$ of their average net profit in the previous 3 years on CSR activities. The Act applies to companies with a net worth of (Indian Rupee) INR five billion or more, or a turnover of INR ten billion or more, or a net profit of INR 50 million or more.

To understand the above-mentioned problem statement, research objectives and questions, the rest of the paper is as follows. Post Introduction in Section I, Section II analyzes and documents the various dilemmas and challenges of an emerging nation - India and thereby points out its national agenda. Section III draws on the recent theoretical literature on the different roles and responsibilities of Corporations in such an economy. Section IV explains the 'Chatterjee model', that urges, from a policymaker's point of view, that CSR should contribute to the social and economic development of an emerging economy, thus helping it to accelerate to a developed nation. This is followed by a Case Study of Tata Housing Development Company Limited (THDCL), to validate the model. Section V is the conclusion, which is followed by Section VI, the way forward.

\section{Dilemmas and challenges of an emerging nation - India}

India has its own challenges as an emerging nation. On one hand it has the world's second largest human population next only to China and predicted to have one of the world's youngest and thereby the largest working population by 2026; yet, on the other hand, it ranks 135 among 186 countries in the Human Development Index (HDI) (Human Development Report, 2013). This means that India has a great volume of people, who have a low life expectancy, education, and per capita income. According to a United Nations Educational, Scientific and Cultural Organisation (UNESCO) report (2014), the country has 287 million illiterate adults, accounting for the largest population globally and $37 \%$ of the world total (Bhowmick, 2014) with just under $10 \%$ having any type of skilling (2\% formal and 8\% informal) (Mitra, 2015c; Mitra \& Schmidpeter, 2016). Or, in other words, unless this population is developed and channelized, it will be a burden not only to India, but also to the world at large.

Moreover, the environmental regulations in India lag behind similar regulations in Organization for Economic Cooperation and Development (OECD) countries by almost a decade and empirical evidence show that Multi National Companies (MNCs) in India and other emerging markets do not necessarily have stricter environmental standards than their local counterparts (Sawhney 1994; Zarsky, 1999; Khan, 2007; Mitra \& Schmidpeter, 2016). Hence, not just socio- economic parameters, but, India also needs to upgrade its environmental indicators to transition into a developed economy.

However, the dilemma lies in the fact that despite such unfortunate socio-economic and environmental indicators, India is home to the sixth largest superrich population (billionaires) in the world. The total billionaire wealth was estimated to be $\$ 180$ billion (Wealth-X and UBS billionaire census report, 2013), bringing India's billionaire population to 103 (Mitra, 2014, 2015c; Mitra \& Schmidpeter, 2016). Therefore, the population is divided between the haves and the have-nots. The country has urban India on one side and rural Bharat on the other.

Although, this rise in inequality, to some extent, is natural in the early stages of economic development (Sharma, 2012), it remains a persistent challenge in many economies today. In Asia and the Pacific, inequality has risen over the last decade despite growth rates that have lowered poverty incidence (Son, 2013). Similarly, in India, although poverty has fallen for every social and religious group in every state and in rural and urban areas, separately as well as jointly between 1993-1994 and 2009-2010 (Panagariya \& Mukim, 2014), yet, the incidences of inequalities are high. This inequality can pose a threat to growth if it goes unchecked (Sharma, 2012).

Hence, it is imperative to have a strategy in place that will: expand opportunities for the poor and protect the poorest and the most vulnerable (O'Sullivan, 1997). Socioeconomic inequality can then be minimised, thus paving the way for an emerging nation to slowly graduate into a developed economy.

Thus, under these circumstances, it is imperative that the national agenda should focus on empowering "the poor and the deprived section of the society" to achieve significant and sustainable human development (Mitra \& Schmidpeter, 2016) and to bring about inclusive growth. In other words, the achievement of inclusive growth in the developing world is a significant challenge for makers in international development (Sen, 2014). 
This concern for inclusive growth, made policymakers increasingly ask age-old questions about how basic health and education systems can be improved, how regulatory systems can function better, who should provide basic services and infrastructure, and how it should be paid for. This led to a 'rediscovery' of underdevelopment, so to speak, and a realization that something is 'missing' in the policy framework (Graham \& Naim, 1997). Thus inequality, earlier measured in terms of income or consumption, has now got extended to cover many other standard of living dimensions such as inequality of outcomes in health, education, and basic infrastructure, among others (Son, 2013). But, whose responsibility is it to provide for the same?

Some think, it is the responsibility of the Government to provide a conducive environment for equality through its social security measures and other policies; while some others think, it is the Corporation that should take the onus in pursuance of their 'social license to operate' objectives. This is often an inconclusive debate, where the perspectives often differ between the developed countries to the emerging countries. What one must remember here is that, the very concept of CSR differs between these two economies in terms of its definition as well as implementation. And, there is no comprehensive, "one size fits all" global corporate governance or CSR system, based on western codes and regulations that can be implemented in emerging markets (Peters et al. 2011), hence, it is better to limit our study of CSR to the emerging markets alone for a focused approach.

\section{Roles and responsibilities of corporations in an emerging economy}

The rationale behind studying CSR in developing countries as distinct from CSR in the developed countries is manifold (Ghosh, 2014):

- developing countries represent the most rapidly growing economies and hence a lucrative growth market for business (IMF, 2006);

- social and environmental crisis is more acutely felt in the developing countries (UNDP, 2006);

- developing countries are the ones where the impact of globalization, economic growth, investment and business activity are likely to have a strong impact on societal and environmental issues (World Bank, 2006) and

- challenges faced by the developing countries with respect to CSR are different as compared to challenges faced by the developed countries.

In a developing country like India, it is increasingly appreciated and not least by business, that to become economic players of first-world magnitude, the challenges of a third-world developmental leap have to be addressed. There is also a sense both among business as well as others (particularly civil society and government) that business has to play a leadership role in bringing about this transformation (Mitra, 2007).

Thus, Indian companies have a very important and difficult role to play in the country's development. It is certainly more complex than the role of corporations in developed economies. Starting much behind their international competitors, both in size and capabilities, Indian companies must rapidly learn to compete with the best in the world. At the same time, they have to compassionately connect with the conditions in their own country and communities around them. This is by no means an easy task (Maira, 2004).

The Private sector, therefore has responsibilities and a role in creating broad based growth and furthering opportunities for individuals in poverty to move up. Involvement of the private sector in development efforts should be encouraged, not only to spur growth, but to make the state more effective by providing competition, increasing equity, and supplementing the resources of the state (The Aspen Institute Conferences, 1997). This needs to be undertaken by the Company through its robust CSR strategy.

After all, this is a symbiotic relationship. As the state/ nation progresses, so does business and vice versa. Any discord in this relationship can cause disequilibrium within the society.

On a micro scale, Mitra (2014) observes that, among other things, it is for the best interest of both the stakeholders (the Government and the governed) that the Government and the Corporations must work hand in gloves to develop the human capital of India to bring about a glorious future. The ideal model, then, would be to generate the continuous 'cycle of conversion' (Fig. 1) and transform the population to reap demographic dividend through a mutually beneficial relationship with the Government and the Corporation. This will not only benefit the Corporations, but also the Government, the population and most importantly, the country, named India (Mitra, 2014, 2015c)!

There are, of course, apart from developing the human capital, many other issues that can be addressed by CSR that can, in its effect contribute to the National Agenda.

It is under this backdrop of an emerging India, with its own challenges and dilemmas, that the Chatterjee model was formulated to streamline the CSR roles and responsibilities of the Corporations and ensure accountability and transparency in their efforts. The propounder of the model, Dr. Bhaskar Chatterjee argues through this model, that 'CSR should contribute to the National Agenda in emerging economies.' 


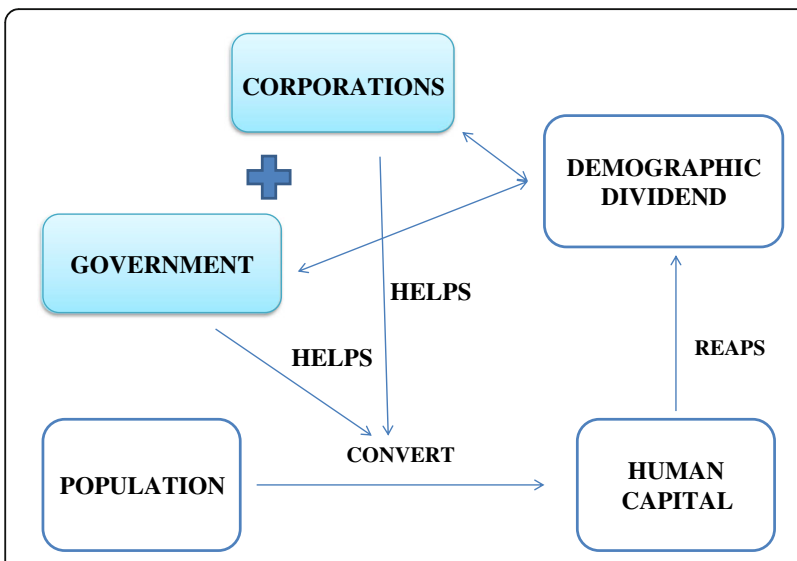

\section{INDIA'S GLORIOUS FUTURE}

Fig. 1 The 'cycle of conversion' of the population to reap demographic dividend Source: Mitra, (2014, 2015c)

\section{The Chatterjee Model}

The Chatterjee model is indeed a unique model, which is different from the Porter model, ${ }^{1}$ Elkington model, ${ }^{2}$ Prahalad model $^{3}$ or any of the known models of CSR . While, all of the rest of the above-mentioned CSR models viewed CSR as a business opportunity, the Chatterjee model of CSR focused on the social developmental agenda of the nation.

Moreover, the Chatterjee model is not only unique to the Indian socio-economic, environmental context; but is also a pioneer in the study of mandated CSR as a new area of research. India is the third country in the world that has a $2 \%$ CSR mandate, next only to Mauritius and Indonesia. However, each one has its own unique features to suit the needs and requirements of their respective countries. In other words, the study of the Chatterjee model is a live study of the CSR mandate in the second most populous country and the largest democracy of the world.

This model was initially launched as the CSR Guidelines for the Public Sector Enterprises of India which became effective from April 1, 2010. Later, Dr. Chatterjee was instrumental in incorporating Section 135 into the Companies Act, 2013 (the Act) (Appendix 1) which made CSR mandatory for certain stable companies having a net worth of (Indian Rupee) INR five billion or more, or a turnover of INR ten billion or more, or a net profit of INR 50 million or more during any financial year. Not stopping there, this Act also laid down a Schedule VII (Appendix 2), detailing the priority areas where such CSR resources needs to be spent.

This Schedule VII of the Act, through repeated amendments, since its formulation, helps prioritise the areas of intervention for the most rapid developmental results and creates the possibility of delivering high impact outcomes while achieving stringent CSR norms and goals. Thus, this CSR mandate has been created 'FOR INDIA, BY INDIA, IN INDIA', keeping in mind the unique Indian context and is 'LINKED TO THE INCLUSIVE DEVELOPMENT AGENDA OF THE NATION' (Chatterjee \& Mitra 2016b).

Let us now understand the different components of the model.

The crux of the Chatterjee Model, lay in the fact that certain large, stable Corporations must ensure certain percentage of CSR spent on specific projects beyond their core business and legislative duties, in areas as laid down in accordance with the National priorities (here, Schedule VII) and should have clear outcome-orientation, have a budget and people assigned to it, and, that can be clearly implemented, measured, reported, audited, thereby harnessing the strength of the Corporations (Fig. 2).

In other words, the model lays stress on projectivisation of CSR activities of these stable Corporations, that ensures complete transparency and accountability. The Company should look at it as a serious endeavor; to really be able to strategize as to what it is doing, why it is doing, what are the results that will flow from there, that will build up to contribute to the National Agenda.

Infact, the moment the word 'PROJECT' is used, it has several connotations: When did it start? When did it end? How much money was allocated to it? What was the baseline survey? What was the documentation? How was CSR monitored? What was the MIS (Management Information System) used? How was it evaluated? How was it assessed? and so on (Chatterjee E Mitra 2016b). Hence, this contribution to national agenda is scientific process driven with a timeline and specific outcome orientation, closely monitored, measured and audited.

This model entails that CSR must be authorized only by the Board of the Company, comprising of three or more Directors, out of which at least one Director shall be an Independent Director and they will be accountable for every decision, every single INR spent on CSR, as well as issuance of a responsibility statement of the CSR Committee confirming that the implementation and monitoring of CSR Policy is in compliance of CSR objectives and Policy of the company. Thus, through this model, CSR, for the first time, came from the backroom to the boardroom.

Further, the Chatterjee model of CSR acknowledges that it is not possible for the mandated companies to directly implement at the grassroot level to bring about this transformation. So, the model propounded that, with the responsibility of projectivisation remaining with the Company, the Companies can implement the CSR projects, approved by the CSR Committee, through civil societies, which in India are certain registered trust or a 


\section{THE 'CHATTERJEE MODEL'}
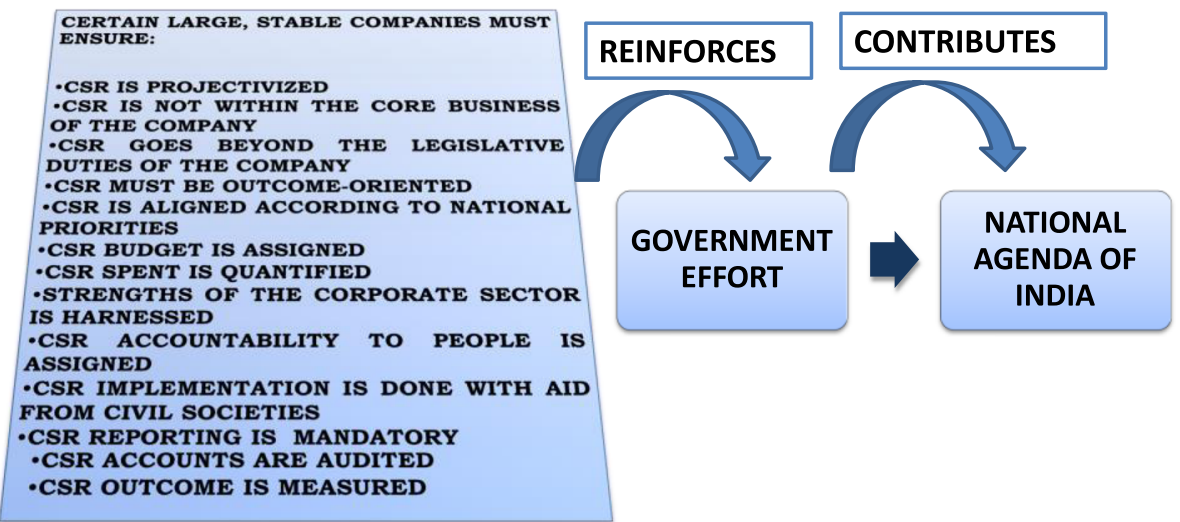

Fig. 2 The 'Chatterjee model'. Source: Authors' own source

registered society or a company established by the company or its holding or subsidiary or associate company under Section 8 of the Company's Act, 2013.

Infact, India has a strength of 3.3 million registered Non-Governmental Organizations that has the experience and expertise of working at the grassroot level. So, the Chatterjee model visualized a plan of partnerships and collaborations, that will build on each other's strengths - the Corporations with its time, money and energy resources; and the partners (civil societies/NGOs) with its manpower (expertise and experience) resources to contribute on the National priorities as laid down by the Schedule VII.

Thus, the CSR implementation strategy, as laid down by the Chatterjee Model can be understood with the help of the following Fig. 3.

To ensure transparency and accountability, this model further makes reporting into the 8-column 'Format for the Annual Report on CSR Activities mandatory to be included in the Board's Report' (Appendix 3). This reporting

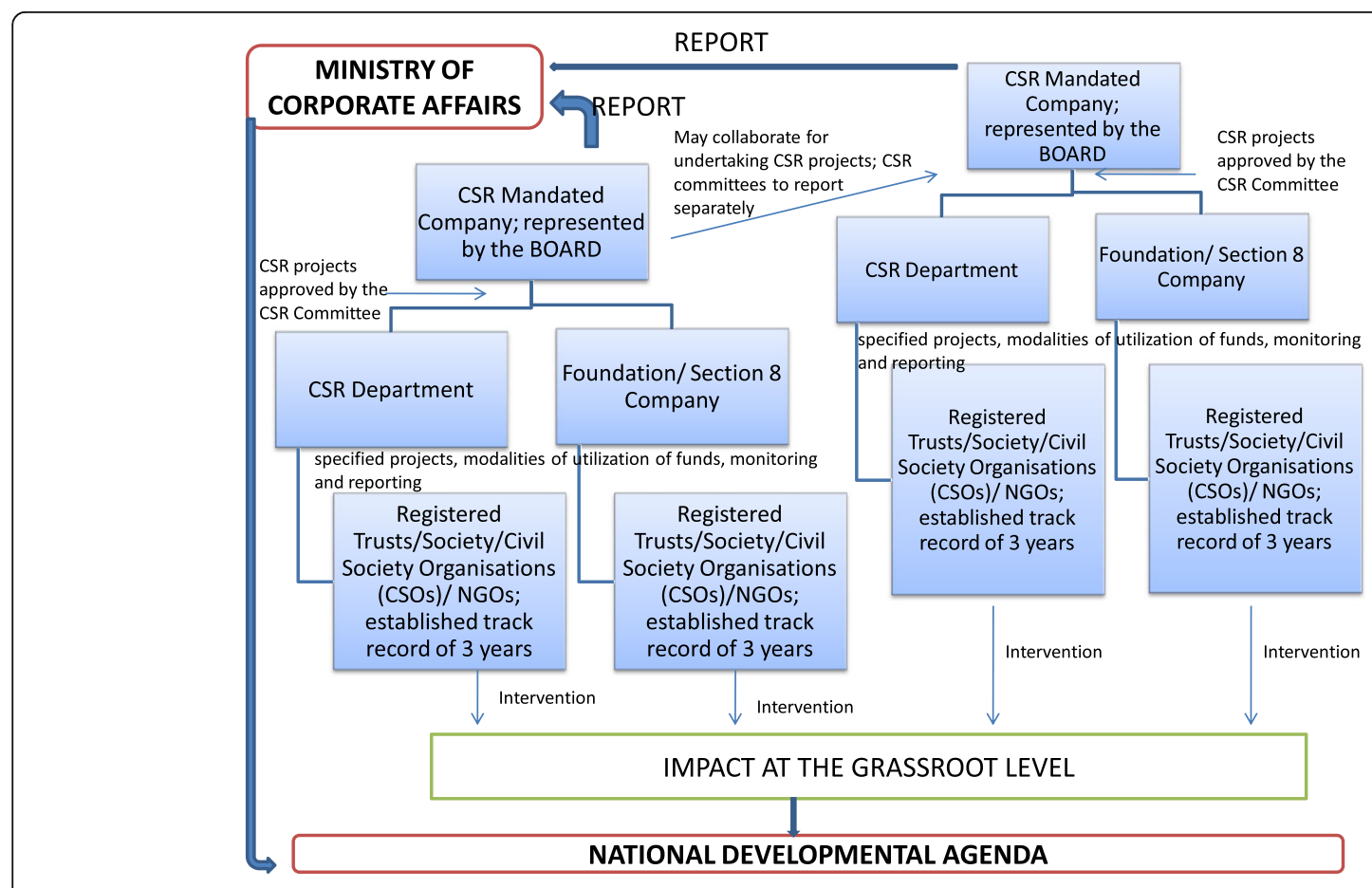

Fig. 3 CSR implementation in INDIA as mandated by the law and how it affects the national developmental agenda. Source: Chatterjee \& Mitra, 2016a 
concept is based on the principle of "comply or explain". This means that although a company should spend $2 \%$ of its net profit on CSR projects and programmes, if, in a financial year, it does not do so, it is called upon to provide an "explanation" on its website and also in the Annual Director's Report. The Government does not stand in judgment on the quality or the validity of the explanation. However, if the company fails to comply with the $2 \%$ norm and also fails to provide any explanation, then it stands to be held accountable under Section 134 of the Companies Act, 2013 which provides for stringent punitive measures (Chatterjee \& Mitra, 2016a). Thus, this entails complete and total transparency for each of the mandated Company.

The Chatterjee model of CSR is a new model. The CSR law in India was passed in the year 2013 and became operational from the Financial Year 2014-15. Empirical research post the passing of the mandate has not yet been generated. Under these circumstances, it is extremely challenging to pinpoint any Company as an example to demonstrate the model. Thus, we have taken the help of the judgements of two experts (one practitioner and one academician) to select the Case Study of the THDCL in order to explore the validity of the model. We do acknowledge the drawbacks of this judgemental sampling approach and understand that this may not empirically produce satisfactory results and, may, therefore, curtail generalizability of the findings due to the fact that we are using a sample of experts that are conveniently available to us. Further, there is no objective way to evaluate the precision of the results. However, due to the unavailability of extant research in this new field of study, we are using this mini Case Study to explore the validity of the Chatterjee Model.

\section{Mini case study of Tata Housing Development Company Limited (THDCL)}

THDCL, a closely held Public Limited Company under 99.86\% subsidiary of Tata Sons, is the first Indian Real Estate Company to have reported the triple bottom-line Global Reporting Initiative (GRI) G4 Sustainability Reporting Guidelines in its Sustainability Report FY 2013-14. It has emerged as the fastest growing company in the real estate sector in India, (since its revival in the late 2006) and has established itself as a "High growth pan India sustainable residential developer". The company has grown its turnover 32 times from INR 360 millions in the Financial Year (FY) 2008 to INR 1146 billion during FY 2014 with a Compound Annual Growth Rate (CAGR) of $37 \%$ in last 5 years (Tata Housing Imprints Sustainability Report 2013-14, 2014; Tata Housing CSR Policy, 2015; Mitra, 2015a, 2015b, 2015c).

In THDCL, the CSR leadership rests at the different management levels, namely, the Board of Directors, Audit Committee, Committee of Directors and the CSR
Committee of the Board, each having specialized role to provide the highest standard of integrity and transparency. The CSR Committee formulates and recommends to the Board, a CSR policy, recommends the amount of expenditure and monitors the CSR Policy of the Company from time to time (Mitra 2015a).

As part of their CSR activities, THDCL started evolving their Community Engagement model from the year 2011 and have gradually developed to comprise of the five broad projects, the names of which are: Tata Affirmative Action Programme (TAAP), SAMARTH, SRIJAN, SWACHH, SPARSH; implemented by the Company's formal and informal structure along with the project partners/NGO partners at the community; conducted within a radius of ten kilometers from the project area (Mitra. 2015a); as documented in Table 1.

Among the above five projects, the first three, namely, TAAP, SAMARTH and SRIJAN contribute directly in developing the human capital of India, one of the key national agendas in improving its socio-economic indicator. Moreover, the Company not only complies to the regulatory environment in India, but also have prioritized its areas of community engagement by reinforcing the Government efforts like that of the 'Skill India" through its project TAAP and SAMARTH and 'SWACHH BHARAT' 5 through its project SWACHH to contribute to the national agenda of India. Moreover, all the five CSR projects of THDCL comply to Schedule VII that was laid down as an indicator of the national priorities in the Company's Act, 2013.

Additionally, the 'cycle of conversion' (Mitra, 2014) has also been followed at THDCL as is evident from the Fig. 4 hereunder:

What is noteworthy here is that, a Real Estate Company like THDCL alone can contribute immensely to the national agenda as is evident from the Case Study. This is extremely promising, especially, at a time, when, according to the Economic Survey of India (FY 2012-13), the real estate sector not only contributes $(5.9 \%$ in FY 2011-12) to India's total Gross Domestic Product (GDP); but also likely to grow in the years to come, becoming the second largest employment generator after agriculture in India (employing nearly 7.6 million across India in 2013) (Roy, 2014, Mitra, 2015c). Therefore, if one sector can bring in substantial change, all the sectors together, under the law and otherwise, can transition India from emerging to a developed economy. This Case Study, thus reinforces the validity of the 'Chatterjee Model' and has a positive impact in its contribution to the national agenda of India.

\section{Conclusion}

The involvement of one company like THDCL, by applying the Chatterjee model into its CSR portfolio in contributing to the national agenda is only the 
Table 1 CSR projects at THDCL

\begin{tabular}{|c|c|c|}
\hline CSR project & CSR project description & Project partners \\
\hline $\begin{array}{l}\text { TATA AFFIRMATIVE } \\
\text { ACTION } \\
\text { PROGRAMME (TAAP) }\end{array}$ & $\begin{array}{l}\text { - attempts to address the prevailing social inequities in India } \\
\text { by encouraging positive discrimination for the SC/ST } \\
\text { communities } \\
\text { - aligned with the framework on affirmative action (AA) } \\
\text { prepared by the Confederation of Indian Industry (CII), which } \\
\text { focuses on four areas of development: employment, } \\
\text { employability, entrepreneurship and education, ie the four Es }\end{array}$ & $\begin{array}{l}\text { Non-Governmental Organisations (NGOs) and Institutions } \\
\text { such as Entrepreneurship Development Institute of India (EDI), } \\
\text { Jay Bharati Foundation, Udyogwardhini, Shikshan Sanstha, } \\
\text { NIIT Foundation and Sambhav Foundation etc. }\end{array}$ \\
\hline SAMARTH & $\begin{array}{l}\text { - provides skill development training to the people other than } \\
\text { SC/ST, thereby 'Enhancing employability, Enabling people'. } \\
\text { - Most of the people trained are in construction related trades } \\
\text { and thereby the company is also nurturing the construction } \\
\text { ecosystem with this project. }\end{array}$ & $\begin{array}{l}\text { civil societies/NGOs like the Pipal Tree, Labournet and } \\
\text { Udyogvardhini }\end{array}$ \\
\hline SRIJAN & $\begin{array}{l}\text { - undertakes several educational development initiatives, } \\
\text { thereby 'Enlightening minds, Empowering masses'. } \\
\text { - not only provides Remedial Coaching to students; but also } \\
\text { helps in up gradation of school infrastructure of schools in } \\
\text { and around project sites. }\end{array}$ & various Schools \\
\hline SPARSH & $\begin{array}{l}\text { - provides community care by taking care of the development } \\
\text { in and around project sites in terms of repair, renovation, } \\
\text { reconstruction and development of roads, community halls, } \\
\text { play grounds etc. and addresses basic survival needs including } \\
\text { relief and rehabilitation, addressing developmental disorders } \\
\text { among children etc., thereby 'Enriching lives, Expanding } \\
\text { avenues.' }\end{array}$ & $\mathrm{Nil}$ \\
\hline SWACHH & $\begin{array}{l}\text { - aims to create an integrated approach of behavioural change } \\
\text { by raising Health and sanitation awareness, construction of } \\
\text { clean toilets etc. in the Schools and Neighbourhoods of the } \\
\text { project area. }\end{array}$ & $\begin{array}{l}\text { Environmental Sanitation Institute (Ahmedabad), Habitat for } \\
\text { Humanity India, and Innovations Unlimited, Gurgaon }\end{array}$ \\
\hline
\end{tabular}

Source: Adapted from the Tata Housing Imprints - Sustainability Report: 2013-14, 2014; Mitra, 2015c

${ }^{a}$ Scheduled Castes (SCs) and Scheduled Tribes (STs) are official designations given to various groups of historically disadvantaged people in India. The terms are recognized in the Constitution of India and the various groups are designated in one or other of the categories. During the period of British rule in India, they were known as the Depressed Classes. In modern literature, the Scheduled Castes are sometimes referred to as Dalits (Scheduled Castes and Scheduled Tribes, 2015)

beginning. The importance of this CSR model in contributing to the national agenda of India can go a long way. The Chatterjee model is thus timely. There is greater need in India, than in the West, to build systems to serve the societal needs for health care, education, and the like (Maira, 2004). Given that the integration into the global economy is crucial to long-term development and poverty eradication, yet so difficult for many countries to achieve, it is essential to identify policies which help countries to capture the benefits of the

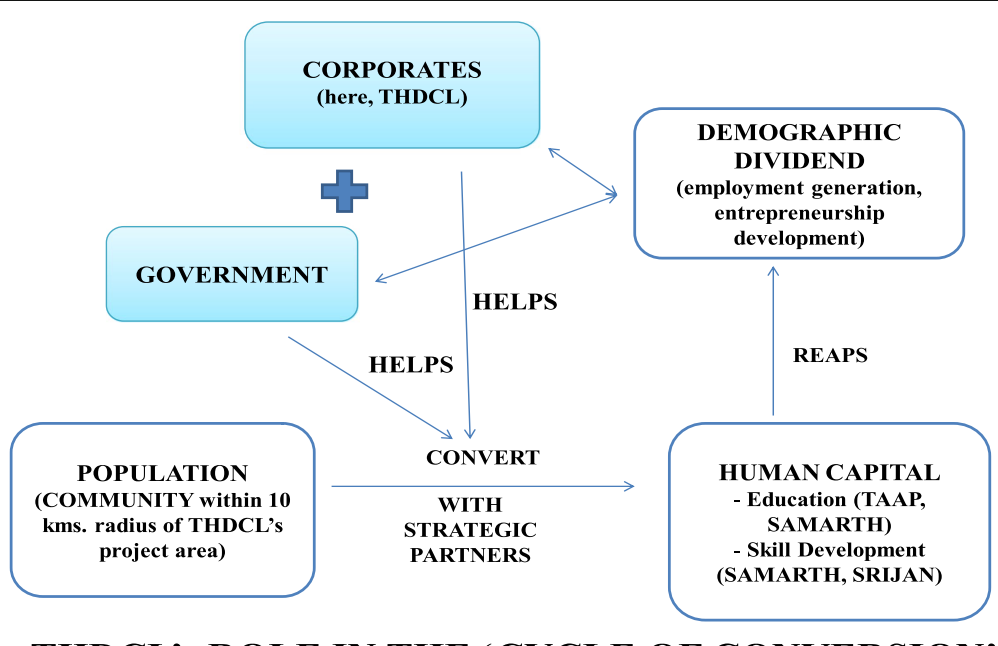

THDCL'S ROLE IN THE 'CYCLE OF CONVERSION'

Fig. 4 THDCL'S role in the 'cycle of conversion'. Source: Mitra, 2015c 
market (O'Sullivan, 1997). Perhaps it is time for Indian business to declare its agenda for fulfilling society's expectations and be seen to live up to it (Maira, 2004).

Thus, under the 'Chatterjee Model,' a new implementation mold of CSR is emerging through the development of strategic partnerships between the Government, civil societies and Corporations. This model, is expected to allow sophisticated analyses of the national problems, create solutions by combining different projects that complement and supplement each other and create scale for a holistic national development agenda in the years to come (Chatterjee \& Mitra, 2016a). To add to this, this model has accountability embedded in its charter. Perhaps, this evaluation of India's mandate can help to develop a framework for how CSR can lead to social well-being in developing countries around the world (Mitra \& Schmidpeter, 2016).

The impact of this model is slated to affect over 16,300 companies with an estimated flow of approximately INR 200 billion annually into the Indian economy every year; thus shaking the foundation of business and society at the same time, affecting the country at a multi-stakeholder level. India is scheduled to be the birthplace of social, economical, environmental transformation through financial investments in CSR! (Mitra \& Schmidpeter, 2016).

\section{Way forward}

This is a very preliminary, yet a vital research that explains the Chatterjee model of CSR as a contributor to the national agenda in an emerging economy such as that of India. It is preliminary as, although, this model has already been mainstreamed as a statute in India, much research needs to be done to analyse the impact of the statute both qualitatively and quantitatively over a period of time, thereby sending in vital information that will be useful for the practitioners - corporates, implementing agencies and Governments, law makers, policy makers alike. This feedback will then act as a benchmark for any corrective action, that may be required. Moreover, the research is also limited by the judgmental sampling of one case study due to the unavailability of extant research in this new field of CSR, so, more case studies need to be done, empirical studies conducted to validate this research. However, this is a very important contribution to the resource of the study of mandated CSR as CSR statute, by itself, is a new area of intervention with Mauritius, Indonesia and India being the only countries under its purview so far.

It is vital as it is one of the first researches that not only distinguishes the concept of CSR between developed and emerging nations; but, also, explains a viewpoint of CSR that is transparent and very objectively contributes to the national agenda of an emerging nation like India, the second most populous country of the world with very poor socio-economic indicators. Moreover, this kind of CSR is unique to India, but further research needs to be conducted to test its replicability in other emerging countries and economies.

\section{Endnotes}

${ }^{1}$ Michael E. Porter and Mark R. Kramer (2011) propounded the concept of 'creating shared value, that states: 'Companies could bring business and society back together if they redefined their purpose as 'creating shared value' - generating economic value in a way that also produces value for society by addressing its challenges. A shared value approach reconnects company success with social progress."

${ }^{2}$ John Elkington (1994) first coined the term, triple bottom line (TBL), that strove to measure sustainability by focusing on comprehensive investment results - that is, with respect to performance along the interrelated dimensions of profits, people and the planet.

${ }^{3}$ C.K. Prahalad (2010) propounded the 'bottom of the pyramid' model, where he argued that one must 'stop thinking of the poor as victims or as a burden and start recognizing them as resilient and creative entrepreneurs and value-conscious consumers, a whole new world of opportunity will open up.'

${ }^{4}$ The main goal of 'Skill India' program, a dream project of the Prime Minister of India, Narendra Modi, launched in March 2015, is to create opportunities, space and scope for the development of the talents of the Indian youth and to develop more of those sectors which have already been put under skill development for the last so many years and also to identify new sectors for skill development. The new program aims at providing training and skill development to 500 million youth of India by 2020 , covering each and every village (Skill India, 2015).

${ }^{5}$ On September 24, 2014, the Prime Minister of India, Narendra Modi approved the Swachh Bharat campaign, which was a modification of the Nirmal Bharat Programme, launched by the previous Government. It was then launched formally on October 2, 2014, the birth anniversary of Mahatma Gandhi, the objective being to make India a clean India by 2019, the 150th birth anniversary of Mahatma Gandhi. The plan is to provide toilet and sanitation facilities in all rural and remote areas, to create public awareness of cleanliness, to clean roads, streets, encroachments and make India one of the cleanest countries of the world (SWACHH BHARAT Abhiyan, 2014).

\section{Appendix 1}

\section{Section 135 of the Companies Act, 2013}

1) Every company having a net worth of INR 5 billion or more, or a turnover of INR 10 billion or more, 
or a net profit of INR 50 million or more during any financial year shall constitute a Corporate Social Responsibility Committee of the Board consisting of three or more directors, out of which at least one director shall be an independent director;

2) The Board's report shall disclose the composition of the CSR Committee.

3) The Corporate Social Responsibility Committee shall:

- formulate and recommend to the Board, a CSR Policy which shall indicate the activities to be undertaken by the company as specified in Schedule VII

- recommend the amount of expenditure to be incurred on these CSR activities

- monitor the CSR policy of the Company from time to time.

4) The Board of these Companies that shall:

a) After taking in account the recommendations made by the CSR Committee, approve the CSR policy for the Company and disclose the contents of such Policy in its report and also place it on the company's website, if any, in such manner as may be prescribed; and

b) Ensure that the activities are included in their CSR Policy and are actually undertaken by the company.

5) The Board of these companies, shall ensure that the company spends, in every financial year, at least $2 \%$ of the average net profits of the Company made during the three immediately preceding financial years, in pursuance of its CSR policy.

Moreover, the Section 135 also provides a direction to these Companies to give preference to the local area and areas around it where it operates, for spending the amount earmarked for CSR activities.

However, the law also states that if the company fails to spend such amount, the Board shall, in its report, specify the reasons for not spending the amount.

\section{Appendix 2}

\section{Schedule VII in the Companies Act, 2013}

i) Eradicating hunger, poverty and malnutrition, promoting preventive health care and sanitation, including contribution to the Swachh Bharat Kosh set-up by the Central Government for the promotion of Sanitation and making available safe drinking water; ii) Promoting education, including special education and employment enhancing vocational skills especially among children, women, elderly, and the differently-abled and livelihood enhancement projects;

iii) Promoting gender equality, empowering women, setting up homes and hostels for women and orphans; setting up old age homes, day care centres and such other facilities for senior citizens and measures for reducing inequalities faced by socially and economically backward groups;

iv) Ensuring environmental sustainability, ecological balance, protection of flora and fauna, animal welfare, agro-forestry, conservation of natural resources and maintaining quality of soil, air and water, including contribution to the Clean Ganga Fund set-up by the Central Government for the rejuvenation of river Ganga;

v) Protection of national heritage, art and culture including restoration of buildings and sites of historical importance and works of art; setting up public libraries; promotion and development of traditional arts and handicrafts;

vi) Measures for the benefit of armed forces veterans, war widows and their dependents;

vii)Training to promote rural sports, nationally recognised sports, para Olympic sports and Olympic sports;

viii)Contributions or funds provided to technology incubators located within academic institutions which are approved by the Central Government;

ix) Rural development projects;

x) Slum development.

\section{Appendix 3}

Format for the Annual Report on CSR activities to be included in the Board's Report

1. A brief outline of the company's CSR policy, including overview of projects or programs proposed to be undertaken and a reference to the web-link to the CSR policy and projects and programs.

2. The composition of the CSR Committee.

3. Average net profit of the company for last three financial years.

4. Prescribed CSR expenditure (two percent of the amount as in item 3 above)

5. Details of CSR spent during the financial year;

a) Total amount to be spent for the financial year;

b) Amount unspent, if any;

c) Manner in which the amount spent during the financial year is detailed below Table 2 . 
Table 2 Format for the annual report on CSR activities

\begin{tabular}{|c|c|c|c|c|c|c|c|}
\hline 1 & 2 & 3 & 4 & 5 & 6 & 7 & 8 \\
\hline $\begin{array}{l}\text { S. } \\
\text { No. }\end{array}$ & $\begin{array}{l}\text { CSR project } \\
\text { or activity } \\
\text { identified }\end{array}$ & $\begin{array}{l}\text { Sector in which } \\
\text { the project } \\
\text { is covered }\end{array}$ & $\begin{array}{l}\text { Projects or programs } \\
\text { (1) Local area or other } \\
\text { (2) Specify the State and } \\
\text { district where the projects } \\
\text { or programs was undertaken }\end{array}$ & $\begin{array}{l}\text { Amount outlay } \\
\text { (budget) project or } \\
\text { program wise }\end{array}$ & $\begin{array}{l}\text { Amount spent on } \\
\text { the projects or programs } \\
\text { Sub-heads: } \\
\text { (1) Direct expenditure } \\
\text { on projects or programs } \\
\text { (2) Overheads }\end{array}$ & $\begin{array}{l}\text { Cumulative } \\
\text { expenditure } \\
\text { upto the } \\
\text { reporting period }\end{array}$ & $\begin{array}{l}\text { Amount spent } \\
\text { Direct or } \\
\text { through } \\
\text { implementing } \\
\text { agency* }^{*}\end{array}$ \\
\hline \multicolumn{8}{|l|}{1} \\
\hline \multicolumn{8}{|l|}{2} \\
\hline \multicolumn{8}{|l|}{3} \\
\hline Total & & & & & & & \\
\hline
\end{tabular}

* Give details of the implementing agency

6) In case the company has failed to spend the two percent of the average net profit of the last three financial years or any part thereof, the company shall provide reasons for not spending the amount in its Board report.

7) A responsibility statement of the CSR Committee that the implementation and monitoring of CSR Policy, is in compliance of CSR objectives and Policy of the company.

This document needs to be signed by the:

\section{i) Chief Executive Officer or Managing Director or Director}

ii) Chairman CSR Committee

iii) Person specified under clause (d) of sub-section (1) of section 380 of the Act; wherever applicable.

\section{Authors' contribution}

Both the authors equally and substantially contributed to the conception drafting and revising of the work. Both the authors have read and approved the final manuscript.

\section{Competing interests}

The authors declare that they have no competing interests.

\section{Author details}

${ }^{1}$ Indian Institute of Corporate Affairs, Gurugram, India. ${ }^{2}$ Developmental Consultant, Kolkata, India.

Received: 17 September 2016 Accepted: 19 January 2017

Published online: 01 February 2017

\section{References}

Bhowmick, N. (2014). 37\% of All the Illiterate Adults in the World Are Indian. Time World. http://world.time.com/2014/01/29/indian-adult-illiteracy/. Accessed 10 Feb 2014.

Chatterjee, B., \& Mitra, N. (2016a). CSR Implementation: How It Is Done In India. In Mitra \& Schmidpeter (Eds.), Corporate Social Responsibility in India: Cases and Developments after the Legal Mandate. Switzerland: Springer International Publishing.

Chatterjee, B., \& Mitra, N. (2016b). The Genesis of the CSR Mandate in India: Demystifying the 'Chatterjee Model'. In Mitra \& Schmidpeter (Eds.), Corporate Social Responsibility in India: Cases and Developments after the Legal Mandate. Switzerland: Springer International Publishing.
Ghosh, S. (2014). A Study of the Participation of the Private Sector Companies of India in Corporate Social Responsibility Activities through Conjoint Analysis. Vision., 18(2), 91-108. SAGE Publications.

Graham, C., \& Naim, M. (1997). The Aspen Institute Conferences on International Peace and Security (Persistent Poverty in Developing Countries : Determining the Causes and Closing the Gaps). England: Broadway.

Human Development Report. (2013). United Nations Development Programme. http://hdr.undp.org/en/countries/profiles/IND/. Accessed 12 Mar 2015.

International Monetary Fund (IMF). (2006) World Economic Outlook: Financial Systems and Economic Cycles. Brussels. International Monetary Fund.

Khan, S. (2007). Corporate Social Responsibility from an Emerging Market Perspective: Evidences from the Indian Pharmaceutical Industry. University of St.Gallen, Business Dissertations. http://www1.unisg.ch/www/edis.nsf/ SysLkpByldentifier/3468/\$FILE/dis3468.pdf. Accessed 11 Jan 2016.

Maira, A. (2004). Remaking India - One country, One Destination. New Delhi: Response Books.

Mitra, M. (2007). It's only Business! India's Corporate Social Responsiveness in a Globalized World. New Delhi: Oxford University Press.

Mitra, N. (2014). CSR should contribute towards developing human capital. Innovation: New Paradigm for Holistic and Sustainable Advancement in Business. Excel India Publishers. ISBN 978-93-83842-36-0.

Mitra, N. (2015a). Mitra, Nayan. 2016. Community Engagement Models in Real Estate - A case study of Tata Housing Development Company Limited (Asian Journal of Business Ethics). Netherlands: Springer. http://link.springer.com/ article/10.1007/s13520-016-0059-1. Accessed April 15, 2016. doi 10.1007/ s13520-016-0059-1.

Mitra, N. (2015b). Role of Corporate Social Responsibility (CSR) in developing the human capital of India: Case Study of Tata Housing Development Company Limited. National conference on 'Skilling for Tomorrow.' Army Institute of Management. November 21, 2015.

Mitra, N. (2015b). Embedded Corporate Social Responsibility through community engagement in the Real Estate sector of India: Case Study of Tata Housing Development Company Limited. Fourth International Conference on Global Business, Economics, Finance and Social Sciences). December 18-20, 2015.

Mitra, N., \& Schmidpeter, R. (2016). The Why, What and How of the CSR Mandate: The India Story. In Mitra \& Schmidpeter (Eds.), Corporate Social Responsibility in India: Cases and Developments after the Legal Mandate. Switzerland: Springer International Publishing.

O'Sullivan, M. (1997). The Aspen Institute Conferences on International Peace and Security (Persistent Poverty in Developing Countries : Determining the Causes and Closing the Gaps). England: Broadway.

Panagariya, A., \& Mukim, M. (2014). A Comprehensive Analysis of Poverty in India. Asian Development Review., 31(1)

Peters, S., Miller, M., \& Kusyk, S. (2011). How relevant is corporate governance and corporate social responsibility in emerging markets? Corporate Governance: The International Journal of Business in Society., 11(4), 429-445.

Rao, K. (2013). India's poverty level falls to record 22\%: Planning Commission. Live Mint and The Wall Street Journal. http://www.livemint.com/Politics/ 1QvbdGnGySHo7WRq1NBFNL/Poverty-rate-down-to-22-Plan-panel.html. Accessed on 10 Feb 2014.

Roy, K. (2014). Real Estate Sector: Economic Significance and Sustainability. Real Estate Digest, 1(11), 44-45.

Sawhney, A. (1994). The New Face of Environmental Management in India. Burlington: Ashgate Publishing. 
Scheduled Castes and Scheduled Tribes. (2015). Scheduled Castes and Scheduled Tribes. https://en.wikipedia.org/wiki/Scheduled_Castes_and_Scheduled_ Tribes. Accessed 18 Sept 2015

Sen, K. (2014). Inclusive growth: When may we expect it? When may we not? Asian Development Review., 31(1).

Sharma, S. D. (1999). Development and Democracy in India. ISBN 1-55587-810-5.

Sharma, R. (2012). The Great Indian Hope Trick. Breakout Nation: In pursuit of the Next Economic Miracle. London: Penguin.

Skill India (2015). http://www.mapsofindia.com/my-india/society/skill-india-a-newprogramme-to-be-launched-in-march-2015. Accessed 18 Sept 2015.

Son, H. H. (2013). Inequality of Human Opportunities in Developing Asia. Asian Development Review., 30(2), 110-130. https://think-asia.org/bitstream/handle/ 11540/1621 Nolume\%2030_No\%202_2013_05.pdf?sequence=1. Accessed 30 Apr 2016.

SWACHH. (2014). BHARAT Abhiyan. http://www.mapsofindia.com/my-india/ society/top-five-programmes-launched-by-prime-minister-narendra-modi-in2014. Accessed 17 Sept 2015.

Tata Housing CSR Policy (2015). http://www.tatahousing.in/csr/csr_policy.php. Accessed 11 Sept 2015.

Tata Housing Imprints - Sustainability Report. 2013-14. (2014). http://www. tatahousing.in/csr/pdf/sr_imprints_2013_2014.pdf. Accessed 11 Aug 2015.

The Aspen Institute Conferences. (1997). The Aspen Institute Conferences on International Peace and Security (Persistent Poverty in Developing Countries: Determining the Causes and Closing the Gaps). England: Broadway.

UNDP. (2006). Beyond Scarcity: Power, poverty and the Global water crisis. Brussels: United Nations Development Programme.

Wealth-X and UBS billionaire census report (2013). http://wuwr.wealthx.com/ Wealth-X\%20and\%20UBS\%20World\%20Ultra\%20Wealth\%20Report\%202013. pdf. Accessed 28 Feb 2015.

World Bank. (2006). World Development Report: 2007. Development and the next generation. Washington: World Bank.

Zarsky, L. (1999). Havens, halo and spaghetti: untangling the evidence about foreign direct investment and the environment (Foreign Direct Investment and the Environment, pp. 47-74). Paris: OECD.

\section{Submit your manuscript to a SpringerOpen ${ }^{\circ}$ journal and benefit from:}

- Convenient online submission

- Rigorous peer review

- Immediate publication on acceptance

- Open access: articles freely available online

- High visibility within the field

Retaining the copyright to your article

Submit your next manuscript at $\gg$ springeropen.com 